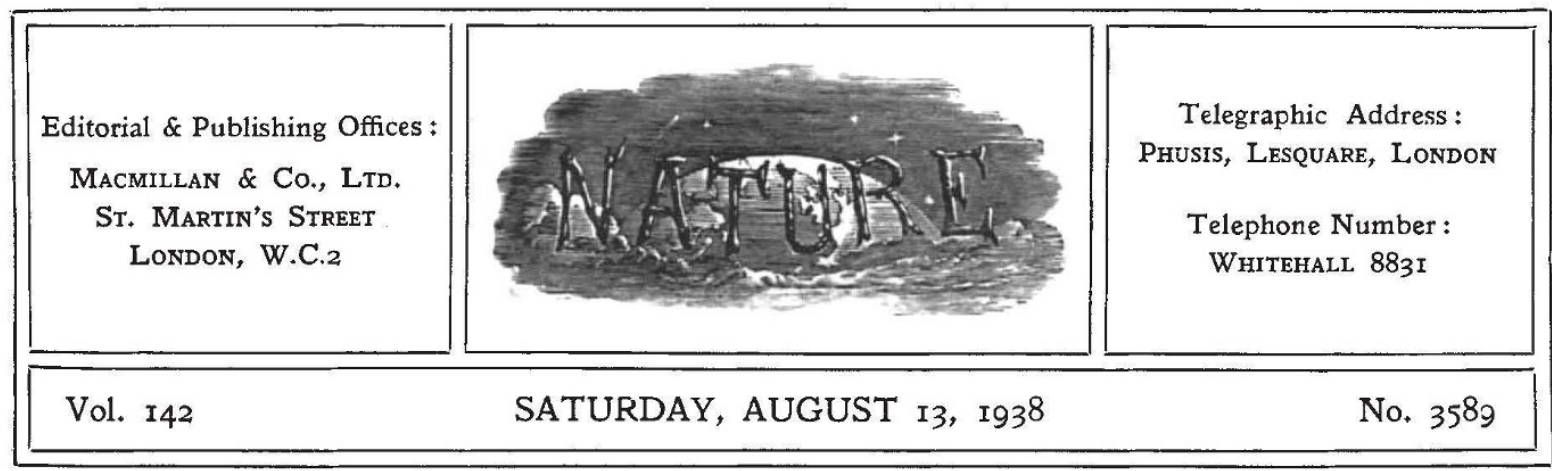

\title{
Inland Water Problems
}

$I^{\mathrm{T}}$ $T$ is inevitable that in a country of the population and extent of the United States of America, the administration of the various public services should be framed on a scale of greater magnitude and amplitude than is practicable or desirable in smaller countries. Yet even if this be admitted, there is no reason why in any two countries, kindred objects of public concern should not be pursued with equal intensity of effort and corresponding breadth of outlook. Where a service is essential for the general welfare, an equivalent degree of enterprise and energy may not unreasonably be expected in both cases.

This reflection presents itself in considering a comparison of the respective attitudes of the British and American Governments in regard to the question of the national administration of water, one of the most essential services of a civilized community. Until recently, in Great Britain there had been no attempt at the effective co-ordination of water resources of the country on a national and systematic basis, and little control over their exploitation beyond the slight and general supervision of Parliament over Bills relating to powers for local supplies. It was left in rather a vague, haphazard way to the Ministry of Health to take action, if and when necessary, with the result that matters in general were allowed to shape their own course, the Ministry only dealing with specific problems as they arose, a characteristically British method, commonly known as 'muddling through'. As for any definite public statement or programme of policy to be adopted for the most efficient and beneficial use of water supplies in regard to the nation as a whole, serious consideration was rarely given to such matters in official or political circles. Indeed, until forced into action by the pressure brought to bear upon Parliament in consequence of the drought of the years 1933 and 1934, and the joint representation of the British Association and the Institution of Civil Engineers, no attempt at a systematic investigation of the water resources of Great Britain was ever contemplated. Only with some degree of ministerial reluctance, after an unsuccessful attempt to describe it as superfluous and unnecessary, was an Inland Water Survey Committee instituted in 1935 under the Ministry of Health. Since then, there has been appointed, also under the Ministry of Health, a Central Advisory Water Committee, which has been engaged in reviewing the work of nine independent Regional Advisory Committees in various parts of the country. The first report of this Central Committee has just been issued, and it affords an indication of the lack of co-ordination which prevails between these bodies and external interests related to water supply.

In the United States, the subject of inland water control has exercised a far greater degree of Governmental consideration and the matter has been dealt with on broad national lines. There is, in the first place, a National Resources Committee dealing with all the national assets of the country, and an important section of this is the Water Resources Committee, including representatives of the War, Interior, and Agricultural Departments, Public Health Service and Federal Power Commission. Through the activities of this body, a co-ordinated plan and policy for each drainage basin in the country has been laid down, and the individual plans have been reviewed 
and co-related in respect of national needs and budgetary limitations. This has been accomplished with the aid of forty-five drainage basin committees, constituted on a democratic basis, with popular representation.

It is pointed out that a unified system of water control, as opposed to a medley of unrelated projects, is essential in the best interests of the nation, and that an integrated federal policy is required in order to deal satisfactorily with various types of water problems having interdependent relationships. The main principles underlying the determination of the adopted programme have been described as a "concern for the promotion of public safety, public health, public convenience and comfort and public economic welfare" so as to secure "the establishment or maintenance of a high standard of living".

Elsewhere in this issue (p. 280) will be found particulars of a six-year programme which has been recommended to Congress, involving in the total an estimated expenditure of 891 million dollars, or a "weighted average" per annum of 200 million dollars-say 40 million pounds. Expenditure on this huge scale indicates profound appreciation of the necessity for a far-reaching development of national resources which, in the case of America, are themselves of enormous magnitude.

The water resources of Great Britain are of much more modest extent, but, none the less, they call for careful conservation and development, and the point may well be raised again, as on a previous occasion (see Nature, August 4, 1934), whether identification of the Inland Water Survey with the restricted outlook of the Ministry of Health is in the best interests of the country. Water is not the special preserve of any particular Government Department : it is a national asset. We have advocated-and still believe the scheme to be best-the establishment of an entirely untrammelled investigation under the Department of Scientific and Industrial Research, the impartiality and independence of which would secure to the nation at large an unbiased outlook on this matter of national concern. The Ministry of Health has its own problems to face, and is not in any way concerned with industrial or commercial requirements, or with the needs of agriculture, fisheries and navigation. It cannot then be claimed that these interests are adequately represented as they should be in a matter of this kind.

The fact of the existence of the Central Advisory
Water Committee does not invalidate our contention in the least. It, too, is a purely departmental Committee and although its functions (inter alix) are "to advise the Government Departments on questions relating to the. conservation and allocation of water supplies", yet, being under the ægis of the Ministry of Health, it cannot, in our view, have that independence of attitude and breadth of outlook which should characterize a committee of this kind. It is true that it includes among its members, individuals associated with a variety of water interests, but none the less it has to supplement its sources of information with the assistance from other departments of "assessors" : one from the Board of Trade, two from the Ministry of Agriculture and Fisheries, one from the Ministry of Transport and one from the Department of Scientific and Industrial Research. If the representations of these assessors are to carry their full weight, the assessors themselves should have the prestige and standing of members of the Committee. The matters with which they deal are not side issues, but questions of serious importance.

We have no intention of making any reflection whatever on the composition of the Inland Water Survey Committee and the Central Advisory Water Committee, or on the particular steps taken by the Ministry of Health to establish them. The cause of criticism lies in the fact that the matter is of such far-reaching importance to all classes of the community that, as in the case of the United States, it calls for the existence of a comprehensive and strictly independent Water Resources Committee on which there would be direct representation of all the varied interests in inland water administration, private as well as corporate. This would naturally include certain Government departments, some of which are remote from the sphere of public health, and relate to the wider aspects of national economy in regard to commerce, transport and industrial development.

A national programme of development drawn up by such an impartial committee would command far greater confidence and support when submitted to Parliament than the unavoidably biased recommendations emanating from a single Ministry. Without such a programme and policy Great Britain must inevitably continue to drift in an aimless way, subject to visitations of drought and flood, and through lack of vision and forethought, reprehensibly neglecting the systematic development of one of the most important natural assets of the country. 